\title{
The Use of Game-Based Student Response Systems during Revision Class to Access Students Performance in Operating System Course
}

\author{
Jacey d/o Mariadass @ Manickam* \\ jacey@puo.edu.my \\ Lecturer, Department of Information and Communication Technology, \\ Polytechnic Ungku Omar, Malaysia
}

\begin{abstract}
The purpose of this study is to investigate whether the use of Game-Based Student Response Systems (GSRS) can increase students' motivation and engagement to perform better in DFC10103 Operating System course in Polytechnic Ungku Omar. This study was conducted by using a quasi-experimental design with pre-test and post-test groups and survey method is used to obtain the data from the participants. The study group consists of 72 operating system course students (Control Group, 36; Treatment Group, 36). Pre-test was given to both groups in order to assess their current performance in this course. Then, revision was done using the GSRS (Kahoot!, Quizizz and Socrative) for the treatment group while a conventional paper-based revision method was carried out with the control group. A post-test was done after the revision class for both groups. After completing the post-test, questionnaire were distributed to the treatment group. Data is analyzed using Statistical Package for Social Science software. The result for post-test shows the treatment group obtained increment in mean percentage as $22.31 \%$ compared to control group. The response given by the participants in the questionnaire shows that the application of GSRS during revision week helped them to stay motivated and engaged in their classroom. Therefore, the outcome shows that GSRS can be a promising and innovative tool for educators to engage with their students in creative learning and attractive competition.
\end{abstract}

Keyword: Game-Based Student Response Systems (GSRS); Student Engagement; Student Motivation; Student Performance

\section{Introduction}

The exploitation and assimilation of technology in 21st century takes place through satisfying environment of learning. Lecturers need to be innovative in designing their pedagogical approach so that students can perform well in the course taken. Traditional activities in the classroom lead to a boring feeling among the students and fail to achieve educational outcomes. Currently many educators are trying to conduct educational games and the results show that they increase students' motivation and engagement (Licorish et al. 2018; Barrio et al. 2016) especially in situation where traditional lecture style or "chalk and talk" teaching are resented by students and induce boredom (Graham 2015; Cheong et al. 2013; Roehl et al. 2013). As a result, students will engage with other tasks such as drawing on their lecture notes and using social media 
such as WhatsApp and Facebook on their mobiles (Morrell and Joyce, 2015). Indeed, in Information and Communication Technology (ICT) Department, maintaining students' motivation and engagement is difficult especially for theoretical course. They get bored when they fail to understand the lesson taught by their lecturers. Courses that focus on theory has been noted to be a challenging area to teach and at the same time the students found them difficult to grasp the knowledge since new terms are being introduced in this course. Besides that, students are restrained to demonstrate their knowledge, ask and answer questions posed by the lecturer publicly due to fear of being seen as attention-seeking by others and disliked by their friends. Students also rarely ask questions in public and prefer to remain anonymous. This situation causes the decrease in students' engagement in the classroom and gives a negative impact on deep learning.

According to Wang (2015), the use of Game-Based Student Response Systems (GSRS) allows students to remain anonymous while interacting with others and grasp new knowledge. It is believed that integrating GSRSs in lectures to test and teach students' course knowledge will increase their motivation, enjoyment and concentration to improve learning performance (Wang and Tahir, 2020). Since the platform such as Kahoot! was released, there are many studies that have been published on the effect of using Kahoot! in the classroom, but so far, there has not been any studies conducted on implementation of various GSRS during revision class in order to keep the students motivated and engaged in the classroom that is believed could lead to better performance. Therefore, this study is conducted in terms of whether the implementation of GSRS in the classroom can motivate the students and make them engage in the classroom in order to perform better for Operating System course. The following research questions (RQs) were defined to achieve the purpose of this research: (i) to identify students' perception on the use of GSRS in Operating System course during revision class in terms of: (a) motivation, (b) engagement, and (ii) to identify whether the use of GSRS in Operating course could help students to perform better in this course. Figure 1 shows the framework for the study conducted for the revision class. In this paper the results of a quasi-experiment were conducted in order to investigate the effectiveness of implementing various GSRS. The rest of this paper is organized as follows; (i) Section 2 present the literature review (ii) Section 3 presents research methodology, (iii) Section 4 presents the findings results from the questionnaire and quasi-experiment. Section 5 concludes the paper. 


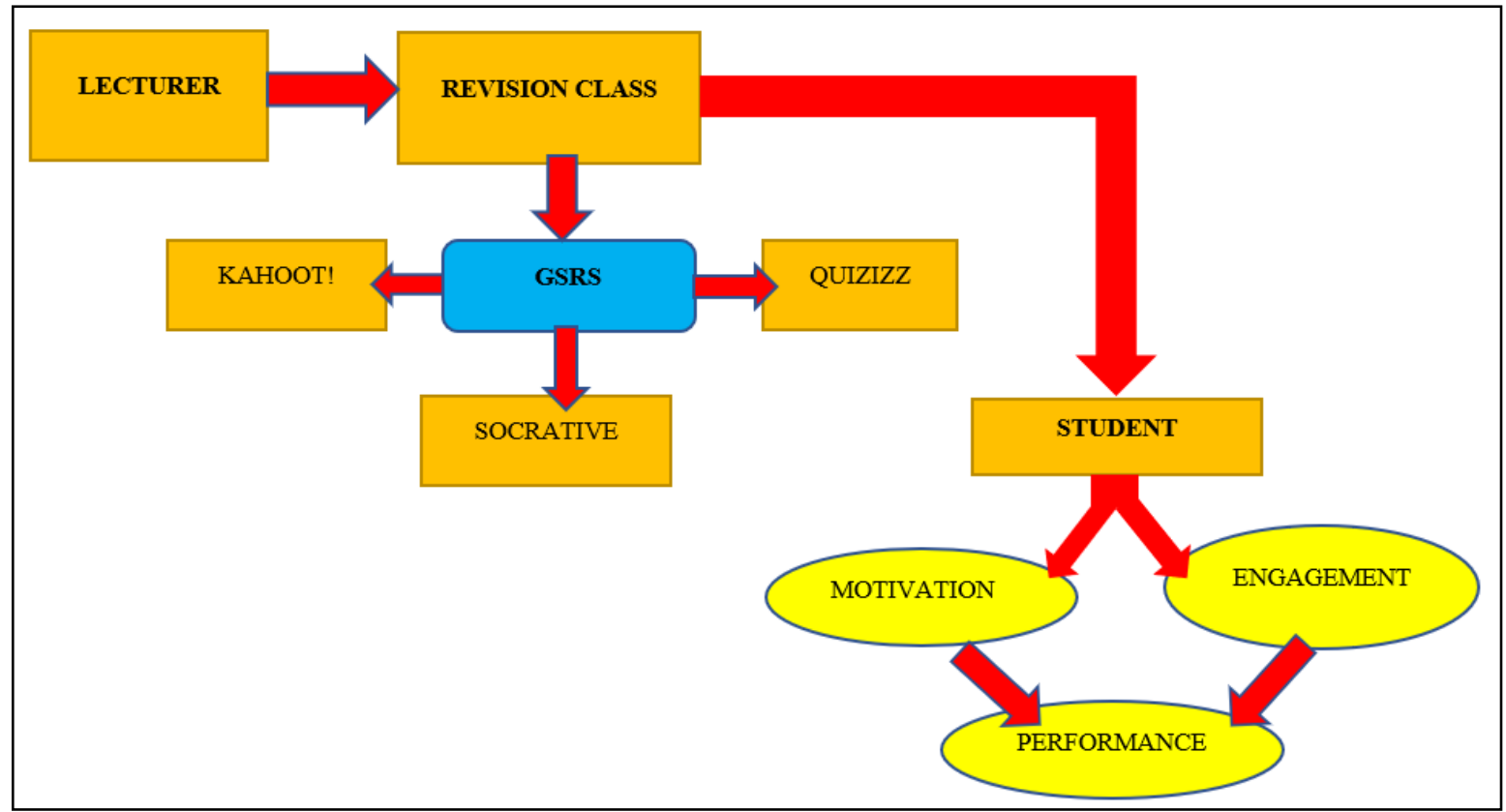

Fig. 1. Framework of the proposed study

\section{Literature Review}

\subsection{Games in education}

Many researchers have studied the roles of games in learning and education. These studies were pioneered by Piaget (1962) and Vygotsky (1978) about the roles of games upon children's development and learning. Currently the revolution of digital technology and computers have given opportunities for the educators in higher education to explore and use the free gamification tools to make their classroom more conducive and enable their students to engage in the class (Lynch, R., Mallon, B., \& Connolly, 2015). Besides that, Bring Your Own Device (BYOD) (e.g. mobile devices) enable students to learn in their own pace. If the classes are conducted outside the computer room, they can still involve themselves in the games conducted by their lecturer. The main intention of the educators are to promote active learning among their students. To keep them active in the classroom, motivation is one of the most important aspect that educators consider to promote active learning. In spite of that, educators realize that their students enjoy playing games which influence their attention and satisfaction which stimulate and sustain students' motivation to learn. The application of gamification techniques in a curriculum can support a more comprehensive activity through its effect on students' sense of interaction, competition and motivation (Asikoy, 2017; Davis et. al, 2018). This is align with ARCS-V Model of motivation (attention, relevance, confidence, satisfaction and volition) (Keller, 
1987 ; Keller, 2010). Figure 2 shows the five components of ARCS-V Model.

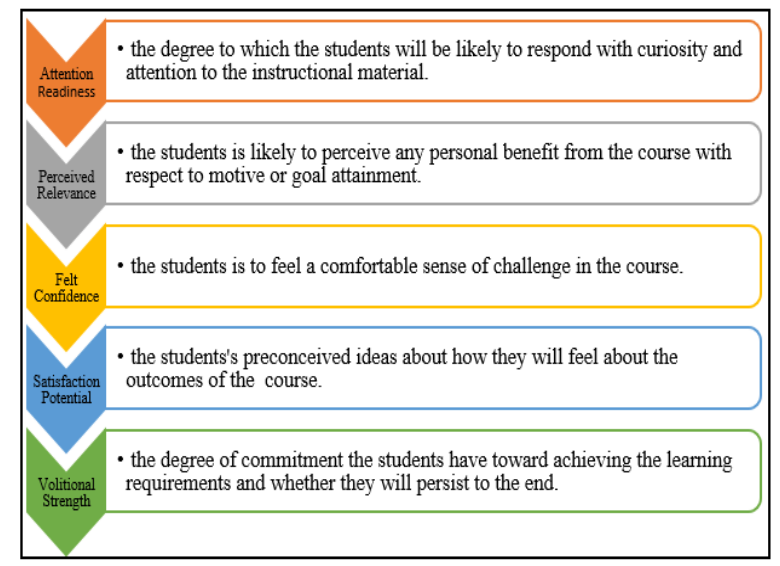

Fig. 2. Components of ARCS-V model

The five components of this model could be achieved through games conducted in the classroom which have the ability to promote fun, engagement and active learning among the students (Gillern and Alaswad, 2016).

\subsection{Game-Based Student Response System}

The use of digital technology increasingly integrated into teaching environment in view of increasing students' motivation and engagement. Many researchers have proven that the use of GSRS such as Kahoot!, Quizizz and Socrative promote in active learning (Plump and LaRosa, 2017). According to Fotaris et.al. (2016), the battle that shows progress bars and levels of students achievement will then lead to greater excitement, which will eventually lead to enhanced students' attention and desire for improvement in the field of teaching and learning. Educators should use games in education as a tool to involve students in activities that combine the element of fun and meaningful learning. To create new opportunities towards this approach, BYOD have played an important role to reshape the way of teaching.

The studies conducted by Boulden et. al. (2017), showed that there is an increase in collaborative learning and engagement as well as improved learning outcomes when the educator use Quizizz as a gaming tool in their classroom. Since both questions and answers are shown on students' devices, there is no necessity to use projector to display the questions like the one use in Kahoot!. Furthermore students do not have to wait for other friends until they finish answering the questions before proceeding to next questions (Chaiyo and Nokham, 2017). The tool can be used to control the level of understanding or lack of knowledge through the 
feedback system provided at the end of the process. Besides that, the use of Kahoot! which is a trend used by the educators as a gaming tool ease the students to receive feedback individually on their devices, promotes self-evaluation in real-time (Nicolaidou, 2018). This condition makes the students to correct their mistakes immediately after the discussion sessions in their classroom. The scoring system effectively gives students motivation to improve the position on the ranking board (Fotaris et.al., 2016). Meanwhile, the educator's report on the distribution of students' responses gives them the opportunity to identify potential gaps, make further analysis as well as explanation of the right choices (Wang, 2015 and Dellos, 2015). Socrative is another GSRS sharing many of the same characteristics with Kahoot! (Coca and Slisko, 2013).

Plump and LaRosa (2017) did a survey upon Business Law undergraduate and graduate students regarding their experience towards the use of Kahoot!. The result from the research showed that students have better understanding towards the law concept as well as an enjoyable learning experience. There is lack of information in their studies because the findings were based on questionnaire and only one of the quiz conducted in the class to assume that the students have better understanding. There is no evidence which shows that the course learning outcomes are achieved. Another research was conducted by Licorish et al. (2018) to acquire students' perceptions of GSRS. It was done by qualitative studies. They conducted an interview with the students regarding their experience towards the use of Kahoot!. Most of the feedback given by the students show that the use of Kahoot! gives them a positive impact. This research seemed to have a limitation due to its smaller sample size (only 14 out of 48 students participated in this studies). The sample is not enough to generalize the study's findings.

\subsection{Motivation and engagement}

Numerous researchers have found a relationship between motivation, engagement and digital games (Mork, 2014 ; Wang, 2015 ; Plum and LaRosa, 2017 ; Licorish et al. , 2018). Motivation is the persuasion to be engaged and interact in the classroom. Where else, students' engagement is related to the level of attention, curiosity, focus and interest that students showed when they attended a course. Research done by Laremnko (2017) in an English as a Second Language (ESL) classroom uses questionnaire to find out which aspects that motivate Ukrainian students to use Kahoot!. The questionnaire was used to measure certain aspects on how students feel about mastery of the material, playing as a team and winning Kahoot!. Results shows that $88 \%$ of the students eager to win the Kahoot! game and that was their motivator to play Kahoot!. To enable them to win the game, students showed more interest in learning because they compete with their friends to win the game. This study aligned with the previous studies conducted by Wang (2015) and Grinias (2017), where the 
challenge among their friends to be top of the ranking board makes them to experience fun and enjoyable learning.

\subsection{Learning performance}

Learning is defined as the knowledge and skills that students attain that are directly attributed to their involvement and participation in the course taken. Many researches have reported that gamifying the learning activity increased the level of challenge to stimulate students' motivation and performance in a learning task (Rincon et al., 2018). Referring to Suh et. al (2018), the ranking board used in Kahoot! and Quizizz have played an important role in improving students' performance by allowing them to see the performance of their friends which lead to stimulate individuals to become more involved in the learning process.

\section{Research Methodology}

\subsection{Participants}

The study is conducted using purposive sampling where samples are chosen among the whole population based on the purpose of the study. The study was conducted among the first semester Diploma Information Technology (Digital Technology) students in Polytechnic Ungku Omar, Malaysia. The samples are the students from the two classes of the Operating System Course. Total of 72 students were involved in this research.

\subsection{Research design}

The study uses quasi-experimental method and survey method. Both method is used based on the relevance of the study. The researcher uses quasi-experimental studies in order to know the impact of using GSRS (Kahoot!, Quizizz and Socrative) during students revision class. This design consists of two groups that is control group and treatment group. Figure 3 shows the procedure used by the researcher. Before the revision class started, both groups were given a pre-test. After the pre-test, control group did paper-based revision activity while the treatment group used GSRS (Kahoot!, Quizizz and Socrative) to prepare for their assessment. Test assessment will be their post-test. The questions for the pre-test and post-test were standardized in order to avoid biasness between both groups. The questions were created by the coursecoordinator. The revision class was conducted for once a week for three weeks. Duration for each revision class was 1 hour. After both groups did their post-test, questionnaire were given to the treatment group to 
assess their perception on the application of GSRS in their revision class in terms of motivation and engagement. Questionnaire were distributed to the participants (treatment group) after their pre-test.

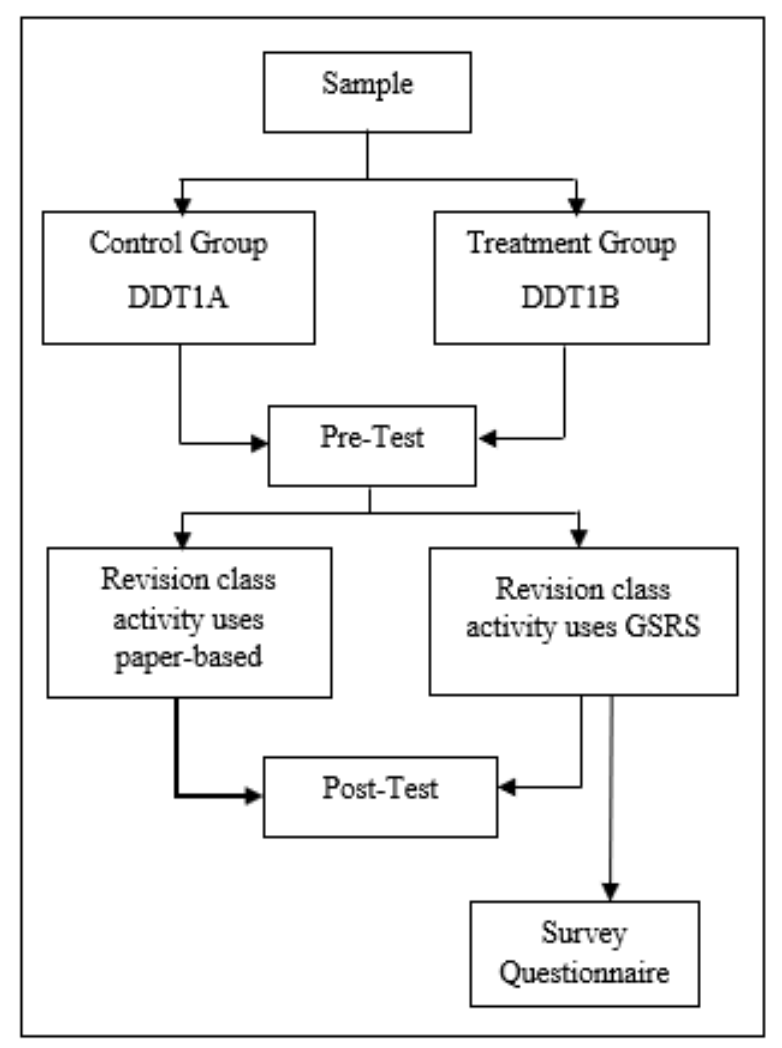

Fig. 3. Pre-test and post-test implementation procedures

Statistic descriptive was used in this studies in order to explain students' response through questionnaire. The items for the questionnaire were adapted from the research done by Plump and LaRosa (2017), Ismail (2017) and Yassine et al. (2019). Items were chosen and edited to fulfilled the requirement of this study. The survey consisted of two main sections: (i) a demographic data section to gather information concerning the participants' age, gender and (ii) a four-point Likert scale survey section where 1 meant strongly disagree and 4 stood for completely agree. The decision to include a four-point scale as to force the participants to take a stance and avoid having students being neutral. The response neutral exist on a five-point scale which enable students to be neutral and the result will not be helpful for this studies. The second session is divided into two dimensions; (i) engagement and (ii) motivation. Students' performance were evaluated based on pre-test and post-test conducted between control group and treatment group. 


\subsection{Data analysis}

The results obtain from pre-test and post-test were analyzed using Statistical Package for Social Science. The marks were analyzed by finding overall min to see whether there is increase between control group and treatment group. The mean for overall marks for pre-test and post-test are sought to see whether the application of GSRS for revision class was able to motivate and keep them engaged and to perform better in the course.

Data analysis was performed descriptively. Likert scale is used to measure the response given for each item in the questionnaire. Participants have to tick their answer chosen for each item in the questionnaire based on the scale strongly disagree to strongly agree. Table 1 shows the likert scale used for this studies.

Table 1. Likert scale

\begin{tabular}{lll}
\hline Score & Level of acceptance & Symbol \\
\hline 1 & Strongly Disagree & SD \\
2 & Disagree & D \\
3 & Agree & A \\
4 & Strongly Agree & SA \\
\hline
\end{tabular}

The responses obtain from the questionnaire were analyzed in order based on items in sections B and C. All data obtained from the participants were collected and analyzed quantitatively. All the data were analyzed using Statistical Package for the Social Sciences (SPSS). The mean score analysis for section B and C was made to find out the perception of participants whether the application of GSRS during the revision class could increase their motivation level to learn in this course. Table 2 shows the mean score interpretation for four-point Likert scale.

Table 2. Interpretation of the mean score of a four min likert scale

\begin{tabular}{ll}
\hline Mean Score & Interpretation of Mean \\
\hline $1.00-1.75$ & Unrelated \\
$1.76-2.50$ & Low \\
$2.51-3.25$ & Medium \\
$3.26-4.00$ & High \\
\hline
\end{tabular}




\section{Findings}

This section comprises the discussion of data analysis from the responses given by the participants. Besides that, this section also consists of the findings regarding students' performance due to the ability to retain understanding and knowledge of the course undertaken due to the application of GSRS during revision class. The result are displayed in table form which consist of mean, frequency and percentage.

\subsection{Section A analysis: Student demographic}

The item for this section are participants' gender, ethnic group and their like towards playing online games. Figure 4 shows the demographic (gender) distribution of the participants in this study. 20 (55.6\%) participants are male while female are $16(44.4 \%)$ participants.

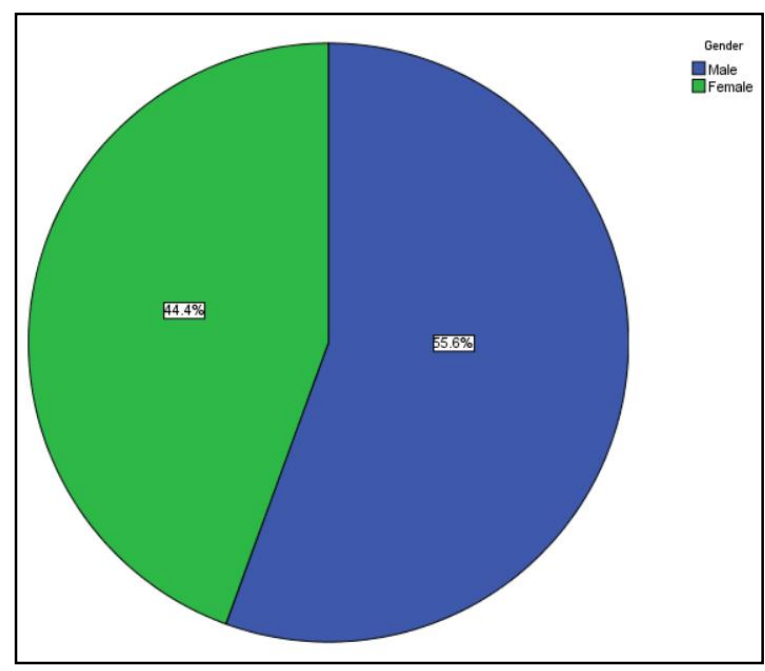

Fig. 4. Demographic (gender) distribution 
Figure 5 shows the participation demographic distribution based on ethnic group. 24(66.7\%) of the participations are Malay while 2(5.5\%) are Chinese, $9(25.0 \%)$ are Indian and 1(2.8\%) participant is others.

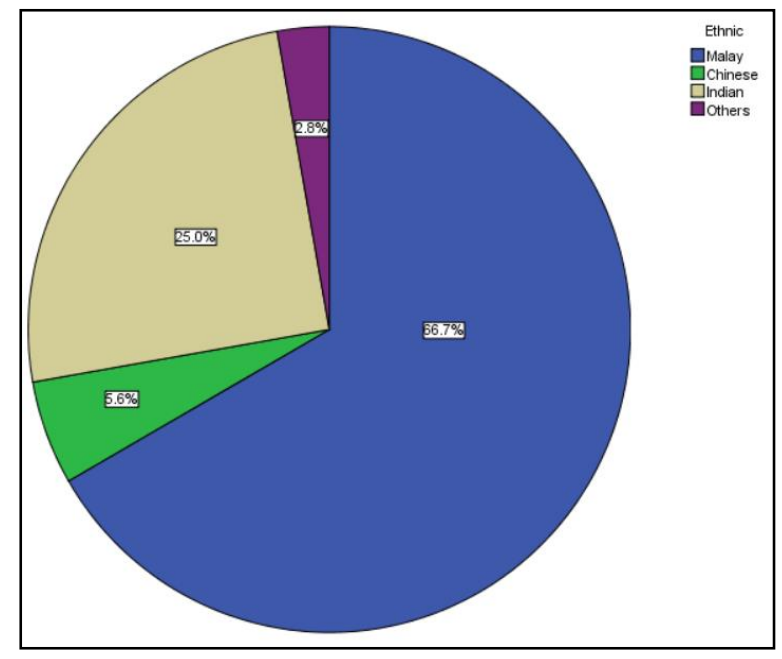

Fig.5. Demographic (ethnic) distribution

Table 3 shows the participants likelihood of playing online games. All the participants show that they like to play online games.

Table 3. Participants demographic distribution

\begin{tabular}{llll}
\hline Likelihood & Yes & 36 & $100 \%$ \\
\cline { 2 - 4 } $\begin{array}{l}\text { Playing online } \\
\text { games) }\end{array}$ & No & 0 & 0
\end{tabular}

4.2 Section B analysis: Students perception towards the application of GSRS related to students motivation during revision class

In this section, the items were used to get participants perception towards the application of GSRS related to their motivation. Table 4 shows the finding for this section. 
Table 4. Motivation aspect

\begin{tabular}{llll}
\hline Item & Item & MD & SD \\
\hline B1 & $\begin{array}{l}\text { Games conducted by my lecturer allow me to stay } \\
\text { focus in class. }\end{array}$ & 0.564 \\
B2 & $\begin{array}{l}\text { The use of GSR has encouraged me to } \\
\text { competitively interact in class. } \\
\text { I will always give a try to answer the questions } \\
\text { because the answers given by me are not known by } \\
\text { my friends. }\end{array}$ & 0.500 \\
& $\begin{array}{l}\text { I will put my effort to answer the questions correctly } \\
\text { in order to be in the leader board and be the best in } \\
\text { the class. }\end{array}$ & \\
B4 & $\begin{array}{l}\text { I always prepare earlier before entering this class in } \\
\text { order to perform well in the games. }\end{array}$ & 0.487 \\
The discussion after games reinforced and enriched \\
by a class discussion encourages me for more in- \\
depth thinking.
\end{tabular}

Table 4 shows that the participants gave positive responses where the mean score for all the items is above 3.50. The highest mean score is 3.72 for item B6. This shows that the participants agreed that a class discussion encourages them for more in-depth learning after the games were reinforced. While the minimum mean score is for item B8 is their lecturer gives them time to explore the answers with their groupmates through discussion is 3.53. This shows that some of the participants feel that the time given for the discussion is insufficient. Item B6 is the lowest standard deviation with 0.454. This shows that the respondents distribution is not wide. Most of the participants agreed that the use of GSRS helps them to stay motivated to in this course to perform better in their exam. The overall min for motivation aspect is 3.63 . 
There is a difference between the responses given by the male and female participants towards the aspect of motivation. The data analysis shows that the highest score mean (3.75) for the responses given by male is for item B7 which indicate that they are able to correct their mistakes with immediate feedback given by their lecturer. While the highest score mean (3.94) for female participants is item B3 and this shows that they always give a try to answer the questions because the answers given by them are not known by their friends. From the research findings of section B, it can be concluded that respondents agreed that the application of GSRS can increase their motivation level to study and perform better in Operating System course.

\subsection{Section C analysis: Students perception towards the application of GSRS related to students engagement during revision class}

The data analysis in this section is regarding students' perception towards the application of GSRS related to their engagement in the revision class. Table 5 shows participants' perception towards the aspect of engagement.

Table 5. Engagement aspect

\begin{tabular}{|c|c|c|c|}
\hline $\begin{array}{l}\text { Item } \\
\text { Num }\end{array}$ & Item & MD & SD \\
\hline $\mathrm{C} 1$ & $\begin{array}{l}\text { I pay attention during the lectures in order to answer } \\
\text { well during games session. }\end{array}$ & 3.72 & 0.454 \\
\hline $\mathrm{C} 2$ & $\begin{array}{l}\text { I examine lecturer's materials closely in order to } \\
\text { prepare for the games and answer the questions } \\
\text { correctly. }\end{array}$ & 3.64 & 0.487 \\
\hline C3 & $\begin{array}{l}\text { I feel refreshed when my lecturer conducts games in a } \\
\text { fun way. }\end{array}$ & 3.69 & 0.467 \\
\hline $\mathrm{C} 4$ & $\begin{array}{l}\text { I feel the unique lecture experience makes learning } \\
\text { more enjoyable. }\end{array}$ & 3.75 & 0.439 \\
\hline C5 & $\begin{array}{l}\text { The games conducted by my lecturer help me to } \\
\text { retain my knowledge of this course. }\end{array}$ & 3.67 & 0.478 \\
\hline C6 & $\begin{array}{l}\text { I could remember the important concepts in this } \\
\text { course when my lecturer recaps what we have learnt } \\
\text { using the games. }\end{array}$ & 3.75 & 0.439 \\
\hline C7 & $\begin{array}{l}\text { The use of the games offer a brief and concise } \\
\text { understanding of the basic concepts in the course. }\end{array}$ & 3.72 & 0.454 \\
\hline $\mathrm{C} 8$ & I don't feel bored during this class. & 3.75 & 0.439 \\
\hline C9 & $\begin{array}{l}\text { The games conducted during revision week act as } \\
\text { revision tool for exam. }\end{array}$ & 3.75 & 0.439 \\
\hline $\mathrm{C} 10$ & $\begin{array}{l}\text { I feel the use of GSRS makes the class more } \\
\text { interactive and lively. }\end{array}$ & 3.67 & 0.478 \\
\hline & Overall Mean for Engagement Aspect & 3.71 & 0.457 \\
\hline
\end{tabular}


There are 4 items that score highest mean. The highest mean score (3.75) for this section are item C4, C6, $\mathrm{C} 8$ and $\mathrm{C}$. Item $\mathrm{C} 4$ shows that most of the participants agreed that they feel a unique lecture experience that makes their learning more enjoyable. Next item C6 shows that they could remember the important concepts in this course when their lecturer recaps what they have learnt using GSRS. Item C8 shows that they don't feel bored during this class and item C9 shows that the games conducted during revision week act as revision tool for exam. While item C2 shows the lowest mean score (3.64). This item shows that they examine lecturer's materials closely in order to prepare for the games and answer the questions correctly. Although this item is the lowest score mean but the mean score is still above 3.5 where the participants' perception towards this item still shows high engagement towards this item. The overall mean score for engagement aspect is 3.71 . Based on the research findings for section $\mathrm{C}$, it can be concluded that respondents highly agreed that the application of GSRS can keep them engaged during revision class.

\subsection{The application of GSRS towards students' performance}

The researcher have chosen 2 classes to investigate whether the application of GSRS can lead to better performance for this course. DDT1A as control group while DDT1B is the treatment group. The application of GSRS was done during revision week for treatment group while a conventional paper-based method was used for the control group. Figure 6 shows the percentages of the results for pre-test and post-test for both classes.

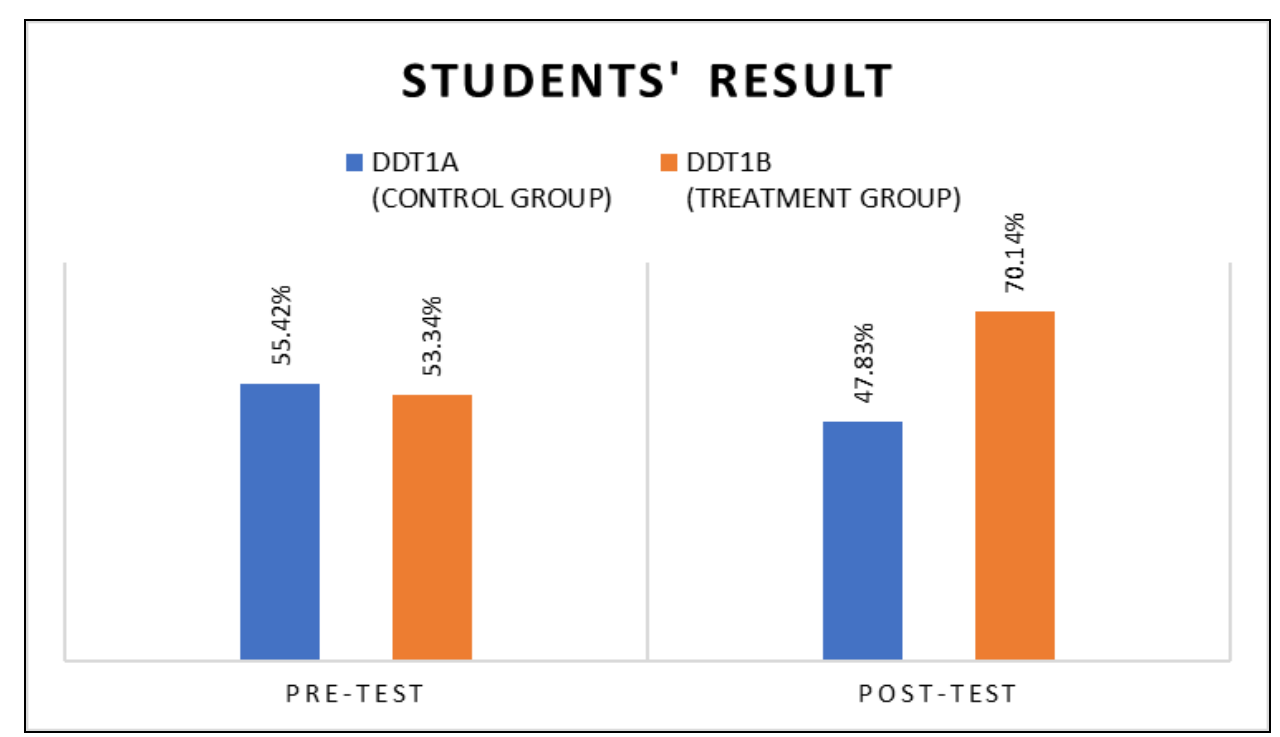

Fig. 6. Students' result between control group and treatment group 
The percentage of the results for pre-test shows that the control group achieved 55.42\% while the treatment group obtained $53.34 \%$. The percentage results of the treatment group for pre-test shows $2.08 \%$ decline compared to the control group. Students' performance for post-test shows increment in students' performance in treatment group compared to the control group which is $22.31 \%$. The result shows that the application of GSRS during revision week can lead to better performance for this course.

\section{Conclusion}

Successful GSRS need to be applied in teaching and learning in order to attract students to learn new courses especially the courses that need understanding and knowledge. The application of GSRS with proper planning could benefit the students as well as the educator. Students will be motivated to learn the course although it is difficult for them. The motivation will keep them engaged in the classroom that can lead to better performance. Further research can be done by using various GSRS to look into their achievement throughout the semester. Also, research need to be done regarding the teaching strategies used such as using mind map to collaborate with students, flip notes, videos and the notes accessibility via QR Codes.

\section{Acknowledgement}

I would like to thank ICT Department, PUO for allowing me to conduct this study and my greatest appreciation to all participants who had participated in this study.

\section{References}

Asiksoy, G., 2017. The Effects of the Gamified Flipped Classroom Environment (GFCE) on Students' Motivation, Learning Achievements and Perception in a Physics Course, Quality \& Quantity, vol. 52, no. 1, p. 129-145.

Barrio, C.M., Munoz Organero, M. and Soriano, J.S., 2015. Can Gamification Improve the Benefits of Student Response Systems in Learning? An Experimental Study, IEEE Transactions on Emerging Topics in Computing, vol. 4, no. 3, p. 429-438.

Boulden, D.C., Hurt, J.W. and Richardson, M.K., 2017. Implementing Digital Tools to Support Student Questioning Abilities: A Collaborative Action Research Report, I.E .: Inquiry In Education, vol. 9, no. 1, p.1-14.

Chaiyo, Y. and Nokham, R., 2017. "The effect of Kahoot, Quizz and Google Forms on the students's perception in the classroom response system," International Conference on Digital Arts, Media and Technology (ICDAMT), Thailand, p. 178-182.

Cheong, C., Cheong, F. and Filippou, J., 2013. Quick Quiz: A Gamified Approach for Enhancing Learning, in Pacific Conference on Information Systems, Korea, p. 156.

Coca, D.M. and Slisko, J., 2013. Software Socrative and Smartphones as Tools for Implementation of Basic Processes of Active Physics Learning in Classroom: An Initial Feasibility Study with Prospective Teachers, European J of Physics Education, vol. 4, no. 2, p. 17 24. 
Davis, K., Sridharan, H., Koepke, L., Singh, S. and Boiko, R., 2018. Learning and Engagement in a Gamified Course: Investigating the Effects of Student Characteristics, Journal of Computer Assisted Learning, vol. 34, no. 5, p. 492-503.

Dellos, R., 2015. Kahoot! A Digital Game Resource for Learning, International Journal of Instructional Technology and Distance Learning, vol. 12 , no. 4 , p. $49-52$.

Fotaris, P., Mastoras,T., Leinfellner R,. and Rosenally, Y., 2016. Climbing up the Leaderboard: An Empirical Study of Applying Gaming Techniques to a Computer Programming Class, The Electronic Journal of e-Learning, vol. 14, no. 2, pp. 94-110.

Gillern, S.V. and Alaswad, Z., 2016. Games and Game-based Learning in Instructional Design, International Journal of Technologies in Education, vol. 23, no. 4, p. 1-17.

Grinias, J., 2017. Making a Game Out of it: Using Web-based Competitive Quizzes for Quantitative Analysis Review, Journal of chemical education, vol. 94 , no.9.

Ismail, M.A. and Jamilah, A.M., 2017. Kahoot: A Promising Tool for Formative Assessment in Medical Education, Education in Medicine Journal, vol. 9, no. 2 pp. 19-26.

Keller, J. M., 1987. Strategies for Stimulating the Motivation to Learn, Performance \& Instruction, vol. 26, no. 8, p. 1 - 7.

Keller, J. M., 2010. Motivational Design for Learning and Performance: The ARCS Model Approach. New York: Springer.

Laremenko, N.V., 2017. Enhancing English Language Learners' Motivation Through Online Games, Information Technologies and Learning Tools, vol. 59, no. 3, p. 126.133 .

Licorish, S.A., Owen, H.E., Daniel, B. and George, J.L., 2018. Students' Perception of Kahoot!s Influence on Teaching and Learning, Research and Practice in Technology Enhanced Learning, vol. 13, no. 9, p. 1-23.

Lowman, G., 2016. Moving Beyond Identification: Using Gamification to Attract and Retain Talent, Industrial and Organizational Psychology, vol. 9 , no. 3, p. 677-682.

Lynch, R., Mallon, B. , and Connolly, C., 2015. The Pedagogical Application of Alternate Reality Games: Using Game-based Learning to Revisit History, International Journal of Game Based Learning (IJGBL), vol. 5, no. 2, p. 18-38.

Mork, C.M., 2014. Benefits of Using Online Student Response Systems in Japanese EFL Classrooms, The Jalt Call Journal, vol. 10, no. 2, p. 127-13.

Morrell, L. and Joyce, D., 2015. Interactive Lectures: Clickers or Personal Devices?, F1000 Research, vol. 4, p. 64.

Nicolaidou, I., 2018. Turn your Classroom into Gameshow with a Game-based Student Response System, in 12th European Conference on Game Based Learning, France, 2018, pp. 487-494.

Piaget, J., 1962. Play, Dreams, and Imitation in Childhood. New York: W.W. Norton \& Co, p. 147-168.

Plump, C.M. and LaRosa, J., 2017. Using Kahoot! in the Classroom to Create Engagement and Active Learning: A Game-based Technology Solution for eLearning Novices, Management Teaching Review, vol. 2, no. 2, pp. 151-158.

Rincon-Flores, E.G., Gallardo, K. and De La Fuente, J.M., 2018. "Strengthening an educational innovation strategy: Processes to improve gamification in calculus course through performance assessment and meta evaluation," International Electronic Journal of Mathematics Education, vol. 13, no. 1, pp. 1-11, 2018.

Roehl, A., Reddy, S. L. and Shannon, G. J., 2013. The Flipped Classroom: An Opportunity to Engage Millennial Students through Active Learning Strategies, Journal of Family and Consumer Sciences, vol. 105, no.2, p. 44-49.

Suh, A., Wagner, C. and Liu, L., 2018. Enhancing User Engagement Through Gamification, Journal of Computer Information Systems, vol. 58 , no. 3 , pp. $204-213$.

Wang, A. I., 2015. The Wear out Effect of a Game-based Student Response System, Computer \& Education, vol. 82, p. $217-227$. 
Wang, A.I. and Tahir, R., 2020. The Effect of Using Kahoot! For Learning - A literature review, Computer \& Education, vol. 149, p. 122.

Yassine, B., Mohammed, E.M. and Abdelhamid, N., 2019. "Investigating the impact of Kahoot! on students' engagement, motivation and learning outcomes: Ifrane Directorate as a case study," International Journal of Advance Study and Research Work, vol. 2, no. 6, pp. 1-9. 